\title{
Inflammatory response gene polymorphisms and their relationship with colorectal cancer risk
}

\author{
Janina Suchy*†1, Ewa Kłujszo-Grabowska ${ }^{\dagger 1}$, Józef Kładny², Cezary Cybulski ${ }^{1}$, \\ Dominika Wokołorczyk ${ }^{1}$, Jolanta Szymańska-Pasternak ${ }^{1}$, \\ Grzegorz Kurzawski ${ }^{1}$, Rodney J Scott ${ }^{3}$ and Jan Lubiński ${ }^{1}$
}

Address: ${ }^{1}$ International Hereditary Cancer Center-Department of Genetics and Pathology, Pomeranian Medical University, Szczecin, Poland, ${ }^{2}$ Department of General and Oncological Surgery, Pomeranian Medical University, Szczecin, Poland and ${ }^{3}$ Discipline of Medical Genetics, Faculty of Health, University of Newcastle and the Hunter Medical Research Institute, Newcastle, NSW, Australia

Email: Janina Suchy* - jansuch@interia.pl; Ewa Kłujszo-Grabowska - ewagrabowska@interia.pl; Józef Kładny - jkladny@sci.pam.szczecin.pl; Cezary Cybulski - cezarycy@sci.pam.szczecin.pl; Dominika Wokołorczyk - dominikawok@o2.pl; Jolanta Szymańska-

Pasternak - jszymanskapasternak@interia.pl; Grzegorz Kurzawski - gkurz@sci.pam.szczecin.pl; Rodney J Scott - Rodney.Scott@newcastle.edu.au; Jan Lubiński - lubinski@sci.pam.szczecin.pl

* Corresponding author †Equal contributors

Published: 23 April 2008

BMC Cancer 2008, 8:1/2 doi:10.1/86/147|-2407-8-1/2
Received: 22 November 2007

Accepted: 23 April 2008

This article is available from: http://www.biomedcentral.com/I47I-2407/8/II2

(c) 2008 Suchy et al; licensee BioMed Central Ltd.

This is an Open Access article distributed under the terms of the Creative Commons Attribution License (http://creativecommons.org/licenses/by/2.0), which permits unrestricted use, distribution, and reproduction in any medium, provided the original work is properly cited.

\begin{abstract}
Backgroud: Patients with chronic inflammatory bowel disease (IBD) are at an increased risk of colorectal cancer (CRC) and it is estimated that one in six persons diagnosed with IBD will develop CRC. This fact suggests that genetic variations in inflammatory response genes may act as CRC disease risk modifiers.

Methods: In order to test this hypothesis we investigated a series of polymorphisms in 6 genes (NOD2, DLG5, OCTNI, OCTN2, IL4, TNF $\alpha$ ) associated with the inflammatory response on a group of 607 consecutive newly diagnosed colorectal cancer patients and compared the results to controls ( 350 consecutive newborns and 607 age, sex and geographically matched controls).

Results: Of the six genes only one polymorphism in TNF $\alpha(-103$ IT/T) showed any tendency to be associated with disease risk $(64.9 \%$ for controls and $71.4 \%$ for CRC) which we further characterized on a larger cohort of CRC patients and found a more profound relationship between the TNF $\alpha-103$ IT/T genotype and disease $(64.5 \%$ for controls vs $74.7 \%$ for CRC cases above 70 yrs). Then, we investigated this result and identified a suggestive tendency, linking the TNF $\alpha$ $103 \mathrm{IT} / \mathrm{T}$ genotype and a previously identified change in the CARDI5/NOD2 gene $(\mathrm{OR}=1.87 ; \mathrm{p}=$ 0,02 for CRC cases above 60 yrs).
\end{abstract}

Conclusion: The association of polymorphisms in genes involved in the inflammatory response and CRC onset suggest that there are genetic changes capable of influencing disease risk in older persons. 


\section{Background}

Biological and epidemiological data indicate a clear association between chronic inflammation and malignancy [1]. Patients with inflammatory bowel disease (IBD), including Crohn disease (CD) and ulcerative colitis (UC), are at increased risk of developing colorectal cancer [2]. Epidemiological and linkage studies strongly suggest the involvement of genetic factors in IBD, especially those associated with inflammation.

Recently, it has been shown that the NOD2/CARD15 (nucleotide oligomerisation domain 2/caspase activating recruitment domain 15) gene is implicated in the susceptibility to Crohn's disease [3,4]. NOD2/CARD15 is expressed intracellularly in monocytes/macrophages and granulocytes, where it activates the nuclear factor NF- $\mathrm{kB}$, making it responsive to bacterial lipopolysaccharides which culminate in the activation of apoptosis [5]. Patients harbouring mutant NOD2 alleles are presumably deficient in the activation of NF- $\mathrm{KB}$ and consequently the appropriate response to bacterial infection [5-7]. Among patients with $\mathrm{CD}$, the frequency of $\mathrm{C}$-insertion mutation in exon 11 of NOD2 is about three times higher compared to control populations [4].

In a previous investigation, we found a significant association between the NOD2 frameshift constitutional mutation (3020insC) and the risk of colorectal cancer in patients diagnosed above the age of 50 years $(\mathrm{OR}=2.23$; $\mathrm{p}=0.0046)[8]$.

The association between IBD and polymorphisms in other inflammation-related genes involved in the innate immune response like DLG5 [9], IL-4 [10], OCTN [11], $\mathrm{TNF} \alpha$ [12] have been reported but their relationship to disease risk requires further investigation. Together, the associations between polymorphisms in inflammatory response genes and IBD make them attractive candidate susceptibility genes for colorectal cancer since approximately 1:6 individuals with IBD will develop malignancy [13]. In addition, there is sufficient evidence to suggest that remodeling of the immune system with age may also alter cancer risk [14] and consequently alterations in the activity of TNF $\alpha$ may become more pronounced with age.

In the present study, we evaluated whether single nucleotide polymorphisms (SNPs) within a number of inflammatory response genes are associated with an increased risk of colorectal cancer. Ten SNPs in the following six genes: NOD2 (2140 C/T, 2722 G/C), DLG5 (113 G/A), OCTN1 (1672 C/T), OCTN2 (-207 G/C), IL4 (-590 C/T) and TNF $\alpha(-308 \mathrm{G} / \mathrm{A},-857 \mathrm{C} / \mathrm{T},-863 \mathrm{C} / \mathrm{A},-1031 \mathrm{~T} / \mathrm{C})$ were screened in a consecutive series of colorectal cancer patients using a two-staged approach.

\section{Methods}

The investigation was performed in two stages, first to preselect candidate genetic variations by determinating the frequency of any alteration in an unselected colorectal cancer population compared to the newborn controls. The second, depth analysis was performed on specifically matched control subjects to the colorectal cancer group.

For the first stage of the study a group of 350 consecutive, newly diagnosed collected patients affected by colorectal adenocarcinomas from the clinical hospital SPSK-2 Szczecin and a group of 350 control subjects (consecutive newborns from the clinical hospitals of Szczecin) were studied.

During the second stage of the investigation a further 257 consecutive, newly diagnosed colorectal cancer (CRC) patients from Szczecin were combined with the first 350 CRC patients to give a final 607 cases and compared to 607 age, year of birth, sex and geographically matched healthy controls from families negative for a cancer family history. The CRC patients - 316 males and 291 females were collected between the years 1996 and 2006 with the average age of disease diagnosis being 63.2 (range 27-92 yrs). Definite diagnosis of Crohn disease has not been established in any CRC patients.

The adult controls were initially identified during the population genetic cancer screening programme performed in West-Pomerania from 2000-2001. Family doctors and community nurses collected questionnaires with cancer family histories from 1258000 (85\%) of the inhabitants. Before inclusion in the study, all selected adults were verified for their pedigree/clinical data at cancer genetic outpatient clinics that were part of our centre.

This investigation was approved by the Institutional Ethics review committee of the Pomeranian Academy of Medicine, Szczecin and informed consent was obtained from all participants prior to enrolment into the study.

DNA samples were extracted from peripheral blood lymphocytes derived from CRC patients and matched controls or from umbilical cord blood of newborns according to method of Miller et al [15].

Cases and controls were genotyped by using the PCRRFLP method described by others for the following SNPs: TNF $\alpha-857,-863,-1031$ [16], TNF $\alpha$-308 [17], IL-4 -590C/ T [18], NOD2 2140C/T, 2722G/C [19], 3020insC [8], DLG5113G/A [9]. Genotyping of OCTN1 1672C/T was performed using the following primers F: TAGTCTGACTGTCCTGATTGGAAGC, R: TGCTTATTCTCCCTAAGGCATTTTGG followed by AluI restriction fragment length polymorphism (RFLP) analysis. 
For OCTN2 -207G/C polymorphism analysis the primers F: CCGCTCTGCCTGCCAGCGGG， R: CAAGACCGTCCGCGGAGGGTAGG and a HpaII RFLP were used. For each SNP studied a random number were taken and subjected to direct sequencing analysis to reduce the risk that the genotypes were a result of genotyping error. The concordance between the samples taken for DNA sequencing compared to PCR-RFLP analysis was 100 percent. If samples failed to amplify after three attempts the sample and its partner were left out of the analysis such that all analyses were performed on matched pairs.

Statistical analysis included a comparison of the prevalence of the genotype frequency in cases versus controls. Odds ratios were generated from two-by-two contingency tables and statistical significance was determined using Fisher's exact test.

Each genetic variant studied was in Hardy-Weinberg equilibrium.

To estimate the genotype/disease interaction the patient group was stratified by age and logistic regression modelling was undertaken [31]. All interaction analyses were based on the genotype comparison using a codominant model.

\section{Results}

The study was performed in two stages to ensure that the Polish population frequencies of the chosen polymorphisms were no different to that reported in the NCBI SNP database [32].

During the first stage of the study ten polymorphisms in six genes were analysed and no significant differences in the frequencies of nine of the variants was observed in the CRC group compared to the newborn control population. Only one polymorphism (TNF $\alpha-1031 \mathrm{~T} / \mathrm{T}$ ) showed a tendency towards being over-represented in the CRC group compared to the newborn control population. The frequency of the TNF $\alpha-1031 \mathrm{~T} / \mathrm{T}$ genotype was $71.4 \%$ in the CRC group against $64.9 \%$ in the newborn control population.

To better define the relationship between the TNF $\alpha$ 1031T/T SNP and cancer risk a further 257 consecutively collected CRC patients were assayed for the presence of the $\mathrm{T} / \mathrm{T}$ genotype and the results compared to an adult

Table I: Screening of polymorphisms tested for association with CRC between cases and sex, age and geographically matched controls.

\begin{tabular}{|c|c|c|c|c|c|c|}
\hline Gene/Change & Age groups & Genotype & Matched controls $n=607$ & CRC cases $n=607$ & OR (95\% Cl) & p-value \\
\hline \multirow[t]{13}{*}{ NOD2/3020insC } & consecutive & WT/WT & $558(91.9 \%)$ & $544(89.6 \%)$ & 1.00 & 0.065 \\
\hline & & WT/insC & $49(8.1 \%)$ & $60(9.9 \%)$ & $1.26(0.85-1.87)$ & \\
\hline & & insC/insC & $0(0 \%)$ & $3(0.5 \%)$ & NA & \\
\hline & $\leq 50$ & WT/WT & $91(91.9 \%)$ & $94(95 \%)$ & 1.00 & 0.38 \\
\hline & & WT/insC & $8(8.1 \%)$ & $5(5 \%)$ & $0.60(0.19-1.92)$ & \\
\hline & $>50$ & WT/WT & 467 (91.9\%) & $450(88.6 \%)$ & 1.00 & 0.038 \\
\hline & & WT/insC & $4 \mid(8.1 \%)$ & $55(10.8 \%)$ & $1.39(0.91-2.14)$ & \\
\hline & & ins C/ins C & $0(0 \%)$ & $3(0.6 \%)$ & NA & \\
\hline & $>60$ & WT/WT & 350 (91.4\%) & $335(87.5 \%)$ & 1.00 & 0.042 \\
\hline & & WT/insC & $33(8.6 \%)$ & $45(11.8 \%)$ & $1.43(0.89-2.29)$ & \\
\hline & & insC/insC & $0(0 \%)$ & $3(0.8 \%)$ & NA & \\
\hline & $>70$ & WT/WT & $168(90.3 \%)$ & $159(85.5 \%)$ & 1.00 & 0.15 \\
\hline & & WT/insC & $18(9.7 \%)$ & $27(14.5 \%)$ & $1.59(0.84-3.01)$ & \\
\hline \multirow{15}{*}{ TNF $\alpha /-1031 \mathrm{~T} / \mathrm{C}$} & consecutive & $T / T$ & $4 I \mid(67.7 \%)$ & $43 \mid$ (7|\%) & 1.00 & 0.14 \\
\hline & & $\mathrm{T} / \mathrm{C}$ & $170(28 \%)$ & 161 (26.5\%) & $0.89(0.69-1.15)$ & \\
\hline & & $\mathrm{C} / \mathrm{C}$ & $26(4.3 \%)$ & $15(2.5 \%)$ & $0.54(0.28-1.04)$ & \\
\hline & $\leq 50$ & $\mathrm{~T} / \mathrm{T}$ & 71 (7I.7\%) & $63(63.6 \%)$ & 1.00 & 0.42 \\
\hline & & $\mathrm{T} / \mathrm{C}$ & $24(24.2 \%)$ & $32(32.3 \%)$ & $1.53(0.81-2.90)$ & \\
\hline & & $\mathrm{C} / \mathrm{C}$ & $4(4 \%)$ & $4(4 \%)$ & $1.19(0.28-5.01)$ & \\
\hline & $>50$ & $\mathrm{~T} / \mathrm{T}$ & $340(66.9 \%)$ & $368(72.4 \%)$ & 1.00 & 0.04 \\
\hline & & $\mathrm{T} / \mathrm{C}$ & $146(28.7 \%)$ & $129(25.4 \%)$ & $0.80(0.6 \mathrm{I}-1.06)$ & \\
\hline & & $\mathrm{C} / \mathrm{C}$ & $22(4.3 \%)$ & II $(2.2 \%)$ & $0.45(0.22-0.95)$ & \\
\hline & $>60$ & $\mathrm{~T} / \mathrm{T}$ & $252(65.8 \%)$ & $276(72.1 \%)$ & 1.00 & 0.059 \\
\hline & & $\mathrm{T} / \mathrm{C}$ & $115(30 \%)$ & 99 (25.9\%) & $0.76(0.55-1.05)$ & \\
\hline & & $\mathrm{C} / \mathrm{C}$ & $16(4.2 \%)$ & $8(2.1 \%)$ & $0.44(0.18-1.05)$ & \\
\hline & $>70$ & $\mathrm{~T} / \mathrm{T}$ & $120(64.5 \%)$ & $139(74.7 \%)$ & 1.00 & 0.084 \\
\hline & & $\mathrm{T} / \mathrm{C}$ & $60(32.3 \%)$ & 43 (23.1\%) & $0.6 \mathrm{I}(0.38-0.96)$ & \\
\hline & & $\mathrm{C} / \mathrm{C}$ & $6(3.2 \%)$ & $4(2.1 \%)$ & $0.57(0.15-2.08)$ & \\
\hline
\end{tabular}


control population that has been matched for year of birth, age, sex and domicile (Table 1). The results reveal that the $-1031 \mathrm{~T} / \mathrm{T}$ genotype in the CRC group overall when compared to the control population was not significantly different in its frequency $(71.0 \%$ vs $67.7 \%)$.

When the consecutively collected CRC group was stratified for age of diagnosis, there appeared to be an association of the TNF $\alpha-1031 \mathrm{~T} / \mathrm{T}$ SNP with later ages of disease diagnosis (see Table 1).

Previously we have shown in the Polish population that the NOD2 3020insC mutation is associated with CRC risk [8], which remained in this new analysis (Table 1). A combined analysis of patients harbouring the NOD2 mutation and the TNF $\alpha-1031 \mathrm{~T} / \mathrm{T}$ SNP was performed. The combined analysis was performed on 607 CRC patients and 607 matched healthy controls in order to determine if the TNFo -1031 T/T SNP acts in association with the NOD2 3020insC change. From this analysis a total of 41 cases were identified in the CRC group compared to 27 in the control group, which revealed an over-representation of the two SNPs in the CRC group compared to the control group (OR 1.50, $\mathrm{p}=0.45$ ). The average age of disease onset in persons harbouring both polymorphisms compared to those only harbouring the TNF $\alpha-1031 \mathrm{~T} / \mathrm{T}$ change was found to 69.8 years of age (range 48-84) compared to non-carriers 65.3 years of age (range 30-92), which was not statistically significant. Conversely, we observed a trend toward a protective effect in that there was an under-representation of the TNF $-1031 \mathrm{C} / \mathrm{C}$ and NOD2 3020ins $C$ negative carriers in the CRC population (OR 0.49, p = 0.45) (see Table 2).

When stratified by age, the association between the TNF $\alpha$ -1031 T/T and NOD2 3020insC carriers and disease became more apparent (see Table 3 ) with age thereby providing further evidence that these two polymorphisms are associated with later onset disease.

\section{Discussion}

In the present study, we compared the frequency of a series of polymorphisms in different inflammatory response genes associated with IBD (DLG5, IL-4, OCTN,
TNF $\alpha$ and NOD2) in colorectal cancer cases against controls. The results indicate that the TNF $\alpha-1031 \mathrm{TT}$ variant frequency had a tendency to be over-represented in the CRC population compared to an unmatched newborn control population and compared to stringently matched controls. In addition, the association observed in the CRC group compared to the matched controls became more apparent when the CRC patients were stratified by age. The increasing association of the TNF $\alpha-1031 \mathrm{~T} / \mathrm{T}$ genotype with the age of diagnosis of colorectal cancer suggests that there is a link between age-related remodeling of the immune system [14] which results in a greater predisposition to disease with aging in the presence of this polymorphism.

Other polymorphisms were also investigated within the TNF $\alpha$ promoter region of the gene $(-857 \mathrm{C} / \mathrm{T},-308 \mathrm{G} / \mathrm{A}$, $238 \mathrm{G} / \mathrm{A}$ ) and they appeared to confer no protective influence on colorectal cancer risk, a finding which is consistent with other observations [20-23]. Nevertheless associations of the TNF $\alpha$ promoter -1031 polymorphism together with the -308 and -238 polymorphisms have also been made with respect to invasive breast carcinoma [24] and an increased risk of gastric cancer [25]. Other malignancies have also been investigated but no significant differences in the distribution of the $-1031 \mathrm{~T} / \mathrm{T}$ variant have been found in nasopharyngeal carcinoma [26] or in malignant melanoma [27]. There is no information about the relationship between the TNF $\alpha-1031 \mathrm{~T} / \mathrm{T}$ polymorphism and colorectal cancer and further studies are necessary to confirm above results.

We have previously reported an association between the NOD2 3020insC mutation and colorectal cancer risk [8] which has been confirmed in two other reports $[28,29]$ but remains controversial as two other reports failed to identify any association $[13,30]$. In this current report, instead of using general population controls to determine whether the frequency of the NOD2 3020insC mutation was over-represented in our CRC population we used an age, year of birth, sex and domicile matched control population and identified a similar association between this mutation and disease. An age dependent trend was also observed for CRC patients over 50 years of age.

Table 2: Combined analysis of TNF $\alpha-103$ IT/C and NOD2 3020insC in consecutively collected CRC cases compared to matched control subjects.

\begin{tabular}{lllllll}
\hline & \multicolumn{4}{c}{ NOD2 WT/WT } & & NOD2 WT/insC + insC/insC \\
\cline { 2 - 7 } Gene & Controls & CRC & OR (95\%Cl) & Controls & CRC & OR (95\% CI) \\
\hline TNF $\alpha$ T/T & 384 & 390 & 1.00 & 27 & 41 & $1.50(0.90-2.49)$ \\
TNF $\alpha$ T/C & 150 & 142 & $0.93(0.71-1.22)$ & 20 & 19 & $0.94(0.49-1.79)$ \\
TNF $\alpha$ C/C & 24 & 12 & $\mathbf{0 . 4 9}(0.24-1.00)$ & 2 & 3 & $1.48(0.25-8.97)$ \\
\hline
\end{tabular}

$P=0.45$ 
Table 3: Frequency of the combined genotypes (TNF $\alpha-103$ IT/C \& NOD2 3020insC) and changes in the OR with increasing age of diagnosis in consecutively collected colorectal cancer patients.

\begin{tabular}{|c|c|c|c|c|c|c|c|}
\hline \multirow[b]{2}{*}{ Age groups } & \multirow[b]{2}{*}{ Gene } & \multicolumn{3}{|c|}{ NOD2 WT/WT } & \multicolumn{3}{|c|}{ NOD2 WT/insC + insC/insC } \\
\hline & & Controls & CRC & OR (95\% Cl) & Controls & CRC & OR (95\% Cl) \\
\hline \multirow[t]{3}{*}{$\leq 50$} & TNF $\alpha$ T/T & 65 & 61 & 1.00 & 6 & 2 & $0.34(0.07-1.80)$ \\
\hline & TNF $\alpha$ T/C & 23 & 29 & $1.36(0.7 \mathrm{I}-2.62)$ & 1 & 3 & $3.18(0.32-31.47)$ \\
\hline & TNF $\alpha$ C/C & 3 & 4 & $1.44(0.31-6.70)$ & 1 & 0 & 0.00 \\
\hline \multicolumn{8}{|l|}{$p=0.22$} \\
\hline \multirow[t]{3}{*}{$>50$} & TNF $\alpha$ T/T & 319 & 329 & 1.00 & 21 & 39 & $1.80(1.04-3.14)$ \\
\hline & TNF $\alpha$ T/C & 127 & 113 & $0.86(0.64-1.16)$ & 19 & 12.6 & $0.82(0.4 I-1.62)$ \\
\hline & TNF $\alpha \mathbf{C} / \mathbf{C}$ & 21 & 8 & $0.37(0.16-0.84)$ & 1 & 3 & $2.95(0.30-28.58)$ \\
\hline \multicolumn{8}{|l|}{$p=0.12$} \\
\hline \multirow[t]{3}{*}{$>60$} & TNF $\alpha$ T/T & 236 & 245 & 1.00 & 16 & 31 & $1.87(1.00-3.52)$ \\
\hline & TNF $\alpha$ T/C & 98 & 85 & $0.83(0.59-1.17)$ & 17 & 14 & $0.80(0.38-1.65)$ \\
\hline & TNF $\alpha$ C/C & 16 & 5 & $0.29(0.11-0.82)$ & 0 & 3 & --- \\
\hline \multicolumn{8}{|l|}{$p=0.02$} \\
\hline \multirow[t]{3}{*}{$>70$} & TNF $\alpha$ T/T & 111 & 119 & 1.00 & 9 & 20 & $2.08(0.91-4.76)$ \\
\hline & TNF $\alpha$ T/C & 51 & 37 & $0.67(0.4 I-I . I I)$ & 9 & 6 & $0.63(0.22-1.83)$ \\
\hline & TNF $\alpha C / C$ & 6 & 3 & $0.46(0.11-1.89)$ & 0 & 1 & -- \\
\hline$P=0.24$ & & & & & & & \\
\hline
\end{tabular}

By undertaking a combined analysis of carriers of the NOD2 3020insC mutation who have the TNF $\alpha-1031 \mathrm{~T} / \mathrm{T}$ genotype and comparing their frequency in the CRC population to the matched control population a more pronounced interaction emerges. There appears to be an overrepresentation of NOD2 3020insC and TNF $\alpha-1031 \mathrm{~T} / \mathrm{T}$ carriers in the CRC group compared to the matched control group suggesting that it is the combined effect of the two polymorphisms that is particularly important and that their influence becomes more profound with age as evidenced by the increasing over-representation of the two polymorphisms in older CRC patients.

Our studies have several obvious limitations: the size of the study population is relatively small and some stratifications were performed that increased the likelihood of false positive outcomes as a result of the multiple comparison testing. Finally, additional larger investigations using other larger patient groups in ours as well as other populations are required to unequivocally determine the role of these SNPs on CRC risk.

\section{Conclusion}

In conclusion, it appears that independently both the TNF $\alpha-1031 T / T$ and the NOD2 3020insC polymorphisms may act as low risk modifiers of colorectal cancer risk.
Together, the evidence presented in this report suggests an additive effect of the two polymorphisms that becomes increasingly important with advancing age with respect to the risk of CRC. Studies on a larger cohort of colorectal cancer cases and matched controls are necessary to clarify the relationship between the TNF $\alpha-1031 \mathrm{~T} / \mathrm{T}$ and NOD2 3020insC polymorphisms and CRC.

\section{Competing interests}

The authors declare that they have no competing interests.

\section{Authors' contributions}

JS participated in the design of the study, carried out the molecular genetic studies, performed the statistical analysis and drafted the manuscript. EK-G participated in the design of the study, carried out the molecular genetic studies and performed the statistical analysis, both authors contributed equally to this work. JK carried out the clinical genetic studies. CC, DW, JS-P carried out the molecular genetic studies. GK conceived of the study, participated in its design. RJS contributed to interpretation of data, coordination and helped to draft the manuscript. JL conceived of the study, participated in its design and coordination and helped to draft the manuscript. All authors read and approved the final manuscript. 


\section{Additional material}

\section{Additional file 1}

Genotype distribution of ten SNPs analysed in a group of 350 CRC cases and 350 controls (newborns). The data provided report the numbers for each genotype of the SNPs analysed in the control and cases group.

Click here for file

[http://www.biomedcentral.com/content/supplementary/14712407-8-112-S1.doc]

\section{Acknowledgements}

We thank Pablo Serrano-Fernandez for help in statistical analyses.

We are grateful to Maia Mroziak-Baszczuk, Arleta Marciniak-Rudy and Ewa Putresza for help and technical assistance.

This work was financially supported by grants: 2 PO5A 07828 from the State Commitee for Scientific Researches, Warsaw, Poland and LSHG-CT2004-5 I2I42 (European Commission).

\section{References}

I. Coussens LM, Werb Z: Inflammation and cancer. Nature 2002, 420:860-7.

2. Munkholm P: Review article: the incidence and prevalence of colorectal cancer in inflammatory bowel disease. Aliment Pharmacol Ther 2003:I-5.

3. Ogura Y, Bonen DK, Inohara N, Nicolae DL, Chen FF, Ramos R, Britton H, Moran T, Karaliuskas R, Duerr RH, Achkar JP, Brant SR, Bayless TM, Kirschner BS, Hanauer SB, Nunez G, Cho JH: A frameshift mutation in NOD2 associated with susceptibility to Crohn's disease. Nature 200I, 4 I I:603-6.

4. Hampe J, Cuthbert A, Croucher PJ, Mirza MM, Mascheretti S, Fisher $\mathrm{S}$, Frenzel H, King K, Hasselmeyer A, MacPherson AJ, Bridger S, van Deventer S, Forbes A, Nikolaus S, Lennard-Jones JE, Foelsch UR, Krawczak M, Lewis C, Schreiber S, Mathew CG: Association between insertion mutation in NOD2 gene and Crohn's disease in German and British populations. Lancet 200I, 357:1925-8.

5. Ogura Y, Inohara N, Benito A, Chen FF, Yamaoka S, Nunez G: Nod2, a Nod I/Apaf-I family member that is restricted to monocytes and activates NF-kappaB. J Biol Chem 200I, 276:48I2-8.

6. Inohara N, Ogura Y, Chen FF, Muto A, Nunez G: Human Nod I confers responsiveness to bacterial lipopolysaccharides. J Biol Chem 200I, 276:255I-4.

7. Gutierrez O, Pipaon C, Inohara N, Fontalba A, Ogura Y, Prosper F, Nunez G, Fernandez-Luna JL: Induction of Nod2 in myelomonocytic and intestinal epithelial cells via nuclear factor-kappa B activation. J Biol Chem 2002, 277:4I70I-5.

8. Kurzawski G, Suchy J, Kladny J, Grabowska E, Mierzejewski M, Jakubowska A, Debniak T, Cybulski C, Kowalska E, Szych Z, Domagala W, Scott RJ, Lubinski J: The NOD2 3020insC mutation and the risk of colorectal cancer. Cancer Res 2004, 64: 1604-6.

9. Stoll M, Corneliussen B, Costello CM, Waetzig GH, Mellgard B, Koch WA, Rosenstiel P, Albrecht M, Croucher PJ, Seegert D, Nikolaus S, Hampe J, Lengauer T, Pierrou S, Foelsch UR, Mathew CG, Lagerstrom-Fermer M, Schreiber S: Genetic variation in DLG5 is associated with inflammatory bowel disease. Nat Genet 2004, 36:476-80.

10. Aithal GP, Day CP, Leathart J, Daly AK, Hudson M: Association of single nucleotide polymorphisms in the interleukin-4 gene and interleukin- 4 receptor gene with Crohn's disease in a British population. Genes Immun 200I, 2:44-7.

II. Peltekova VD, Wintle RF, Rubin LA, Amos CI, Huang Q, Gu X, Newman B, Van Oene M, Cescon D, Greenberg G, Griffiths AM, St George-Hyslop PH, Siminovitch KA: Functional variants of OCTN cation transporter genes are associated with Crohn disease. Nat Genet 2004, 36:47I-5.
12. Negoro K, Kinouchi Y, Hiwatashi N, Takahashi S, Takagi S, Satoh J, Shimosegawa T, Toyota T: Crohn's disease is associated with novel polymorphisms in the 5'-flanking region of the tumor necrosis factor gene. Gastroenterology 1999, I I 7:1062-8.

13. Lakatos PL, Hitre E, Szalay F, Zinober K, Fuszek P, Lakatos L, Fischer S, Osztovits J, Gemela O, Veres G, Papp J, Ferenci P: Common NOD2/CARD 5 variants are not associated with susceptibility or the clinicopathologic characteristics of sporadic colorectal cancer in Hungarian patients. BMC Cancer 2007, 7:54.

14. Shurin MR, Shurin GV, Chatta GS: Aging and the dendritic cell system: Implications for cancer. Crit Rev Oncol Hematol 2007.

15. Miller SA, Dykes DD, POlesky HF: A sample salting out procedure for extracting DNA from human nucleated cells. Nucleic Acids Res 1988, 16:1215.

16. Grutters JC, Sato H, Pantelidis P, Lagan AL, McGrath DS, Lammers JWJ, van den Bosch JMM, Wells AU, duBois RM, Welsh KI: Increased frequency of the uncommon tumor necrosis factor -857T allele in British and Dutch patients with sarcoidosis. Am J Respir Crit Care Med 2002, I 65: I I I9-I I 24.

17. Mitchell SA, Grove J, Spurkland A, Boberg KM, Fleming KA, Day CP, Schrumpf E, Chapman RW: Association of the tumor necrosis factor -308 but not the interleukin $10-627$ promoter polymorphism with genetic susceptibility to primary sclerosing cholangitis. Gut 200I, 49:288-294.

18. Rigoli L, Bella D, Procopio V, Barberio G, Barberi I, Caminiti L, La Grutta S, Briuglia S, Salpietro CD, Pajno GB: Molecular analysis of sequence variants in the Fc $\varepsilon$ receptor I $\beta$ gene and IL-4 gene promoter in Italian atopic families. Allergy 2004, 59:2 I3-218.

19. Heliö T, Halme L, Lappalainen M, Fodstad H, Paavola-Sakki P, Turunen $U$, Färkkilä M, Krusius T, Kontula K: CARD I5/NOD2 gene variants are asociated with familially occurring and complicated forms of Crohn's disease. Gut 2003, 52:558-562.

20. Landi S, Gemignani F, Bottari F, Gioia-Patricola L, Guino E, Cambray M, Biondo S, Capella G, Boldrini L, Canzian F, Moreno V: Polymorphisms within inflammatory genes and colorectal cancer. J Negat Results Biomed 2006, 5: I5.

21. Landi S, Moreno V, Gioia-Patricola L, Guino E, Navarro M, de Oca J, Capella G, Canzian F, Bellvitge Colorectal Cancer Study Group: Association of common polymorphisms in inflammatory genes interleukin (IL)6, IL8, tumor necrosis factor alpha, NFKBI, and peroxisome proliferator-activated receptor gamma with colorectal cancer. Cancer Res 2003, 63:3560-6.

22. Theodoropoulos G, Papaconstantinou I, Felekouras E, Nikiteas N, Karakitsos P, Panoussopoulos D, Lazaris ACh, Patsouris E, Bramis J, Gazouli M: Relation between common polymorphisms in genes related to inflammatory response and colorectal cancer. World J Gastroenterol 2006, I 2:5037-43.

23. Jang WH, Yang YI, Yea SS, Lee YJ, Chun JH, Kim HI, Kim MS, Paik KH: The -238 tumor necrosis factor-alpha promoter polymorphism is associated with decreased susceptibility to cancers. Cancer Lett 200I, 166:41-6.

24. Sirotkovic-Skerlev M, Cacev T, Krizanac S, Kulic A, Pavelic K, Kapitanovic S: TNF alpha promoter polymorphisms analysis in benign and malignant breast lesions. Exp Mol Pathol 2007, 83:54-8.

25. Sugimoto $M$, Furuta $T$, Shirai $N$, Nakamura A, Xiao F, Kajimura $M$, Sugimura $H$, Hishida $A$ : Different effects of polymorphisms of tumor necrosis factor-alpha and interleukin-I beta on development of peptic ulcer and gastric cancer. J Gastroenterol Hepatol 2007, 22:5I-9.

26. Ho SY, Wang YJ, Huang PC, Tsai ST, Chen $\mathrm{CH}$, Chen $\mathrm{HH}$, Chang CJ, Guo HR: Evaluation of the associations between the single nucleotide polymorphisms of the promoter region of the tumor necrosis factor-alpha gene and nasopharyngeal carcinoma. J Chin Med Assoc 2006, 69:35I-7.

27. Nikolova PN, Pawelec GP, Mihailova SM, Ivanova MI, Myhailova AP, Baltadjieva DN, Marinova DI, Ivanova SS, Naumova Ej: Association of cytokine gene polymorphisms with malignant melanoma in Caucasian population. Cancer Immunol Immunother 2007, 56:37I-9.

28. Papaconstantinou I, Theodoropoulos G, Gazouli M, Panoussopoulos D, Mantzaris G], Felekouras E, Bramis J: Association between mutations in the CARD I 5/NOD2 gene and colorectal cancer in a Greek population. Int J Cancer 2005, I | 4:433-5.

29. Roberts RL, Gearry RB, Allington MD, Morrin HR, Robinson BA, Frizelle FA: Caspase recruitment domain-containing protein 
15 mutations in patients with colorectal cancer. Cancer Res 2006, 66:2532-5.

30. Alhopuro P, Ahvenainen T, Mecklin JP, Juhola M, Jarvinen HJ, Karhu A, Aaltonen LA: NOD2 3020insC alone is not sufficient for colorectal cancer predisposition. Cancer Res 2004, 64:7245-7.

31. Solé X, Guinó E, Valls J, Iniesta R, Moreno V: SNPStats: a web tool for the analysis of association studies. Bioinformatics 2006, 22: $1928-9$

32. NCBI SNP database [http://www.ncbi.nlm.nih.gov/sites/ent $\underline{r e z}$ ? $d b=$ snp\&cmd=search\&term]

\section{Pre-publication history}

The pre-publication history for this paper can be accessed here:

http://www.biomedcentral.com/1471-2407/8/112/pre pub

Publish with Bio Med Central and every scientist can read your work free of charge

"BioMed Central will be the most significant development for disseminating the results of biomedical research in our lifetime. "

Sir Paul Nurse, Cancer Research UK

Your research papers will be:

- available free of charge to the entire biomedical community

- peer reviewed and published immediately upon acceptance

- cited in PubMed and archived on PubMed Central

- yours - you keep the copyright

Submit your manuscript here:

http://www.biomedcentral.com/info/publishing_adv.asp 